\title{
Combined effect of crop rotation and carabid beetles on weed dynamics in arable fields
}

\author{
Reto Schmucki ${ }^{1 *}$, David A. Bohan ${ }^{2}$, Michael J.O. Pocock ${ }^{1}$
}

1. UK Centre for Ecology \& Hydrology, Maclean Building, Crowmarsh Gifford, Wallingford, OX108BB, UK.

2. Agroécologie, AgroSup Dijon, INRAE, Université de Bourgogne Franche-Comté, F-21000 Dijon, France

* Corresponding author-retoschm@ceh.ac.uk

\begin{abstract}
Weed management is a resource-intensive practice in arable agriculture, with direct and long-term impacts on both productivity and biodiversity (e.g. plant, pollinators and farmland wildlife). In conventional systems, weed control relies on crop management and herbicide in puts, but for more sustainable production systems, use of herbicides needs to be reduced. This requires a good understanding of the processes that regulate arable weed dynamics in arable fields.
\end{abstract}

We adopted a systems framework to understand and model interacting components that drive the weed dynamics in 168 arable fields. Within this framework, we built a structural equation model (SEM) to quantify the direct and indirect effects of crop rotation (i.e. crops in the previous three years and the current year) and carabid beetles (Coleoptera: Carabidae) on weed density, seed abundance and accumulation in the seedbank. We included results from a mechanistic approach to infer interactions between seed-feeding carabid beetles and seeds to estimate predation pressure in each field.

Our results show that weeds in arable fields are regulated by crop type, sowing season, and activity density of carabid beetles. We found a direct effect of crop rotation, including both past and current field management practice, on weed abundance in the field and its seedbank. There was also an indirect effect of crops on weed seed accumulation in the seedbank via the effect of seed -eating 
carabid beetles. The efficiency of weed control by carabid beetles depended on the cumulative predation pressure, which indicates the importance of function al diversity as well as abundance. Farmers and agronomists can capitalise on the ecosystem services provided by carabid beetles by adapting agronomic practices and crop rotation to maintain a rich fauna of seed-eating carabids in fields and potentially across the agricultural landscapes. When integrated with rotational management practices, this ecosystem services can improve the efficiency of weed management and contribute to the sustainability of cropping systems.

Keywords: Agroecology, ecological intensification, farm scale evaluations, food security, integrated pest management, trophic interactions.

\section{Introduction}

Weed regulation is essential for securing crop yields and quality, as well as for the long-term productivity of arable cropping systems. In conventional agriculture, herbicides and mechanical treatments are the primary tactics used to control competition of weeds with crops. Despite growing concerns about the consequence of the intensive use of agrochemicals on biodiversity (Freemark and Boutin, 1995) and the wider environment (Cross and Edwards-Jones, 2011; Moss, 2008; Silva et al., 2019), the quantity of herbicide use keeps increasing in many regions around the globe (FAO, 2020). Intensive use of herbicides results in important declines of arable plants (Richner et al., 2015; Sutcliffe and Kay, 2000), invertebrates (Bretagnolle and Gaba, 2015; Kraus and Stout, 2019; Pleasants, 2017) and farmland wildlife (Barré et al., 2018; Gibbons et al., 2006; Smart et al., 2000). Such losses in biodiversity undermine the provision of key ecosystem services upon which the productivity and the economy of agroecosystems depend (Bommarco et al., 2013), stressing the need to develop more sustainable approaches that better integrate the benefits of ecological weed regulatory processes.

In many cropping systems, farmers combine several agronomic strategies such as crop diversification, tillage with selective post-emergence herbicides to control weed population outbreaks. This approach offers a cost-effective strategy, but remains highly dependent on synthetic herbicides and is therefore vulnerable to evolution of herbicide resistance (Hicks et al., 2018). Better integration of ecological understanding is urgent, not only to reduce the impact on the environment but also to increase its efficiency and secure long-term productivity of arable systems (Petit et al., 2018). To harness theirfull potential, integrated weed management approaches must adopt 
strategies that target different stages of the life cycle to contain their density above ground and their accumulation in the seedbank (MacLaren et al., 2020). By carefully designing crop rotations, farmers can influence weed demography by altering the degree of crop-weed competition, the timing of crop emergence, as well as the density and the height of the vegetation cover. Crop rotations offer many levers to apply diverse selective pressure on weed populations to manage their abundance and composition above ground and in the seedbank (Bohan et al., 2011b; Murphy et al., 2006). Weed seed predation by ground beetles (Coletptera:Carabidea) can reduce seed accumulation in the seedbank and contribute to weeds regulation and cropping systems (Bohan et al., 2011a; Carbonne et al., 2020; Frei et al., 2019; Kulkarni et al., 2015; Petit et al., 2018). Post-dispersal seed predation by carabid beetles is well documented, with studies having focussed on their diet and foraging behaviour (Deroulers and Bretagnolle, 2019; Gaba et al., 2019; Honek et al., 2013; Petit et al., 2014), their distribution in arable fields (Lami et al., 2020), and their response to the surrounding landscape (Petit et al., 2017; Trichard et al., 2014).

Although a growing body of work that shows how crop rotation, agronomic practices and seed predation by carabid beetles contribute to regulating of weeds in arable fields, their effects must be considered as part of a comprehensive system (Hawes et al., 2016) where weed dynamics are influenced by both agronomic and ecological factors. Such approaches are also necessary to identify tradeoffs between the costs of arable weeds, and their benefits, e.g. in supporting regulating services (Bretagnolle and Gaba, 2015), and to adequately measure the direct and indirect impacts of specific cropping systems and integrated management practice s on weed regulation (Mézière et al., 2015).

Here we investigate the direct and indirect effects of crop rotation, field management and seed predation on the density and the dynamics of arable weed communities. We built a conceptual model that explicitly integrates the action of both agronomic and ecological drivers on weed dynamics and at each stage of their life cycle (see Structural Equation Model in Methods) and is based on theoretical knowledge and results obtained from previous investigations. Using structural equation models (SEM), we then tested this conceptual model against empirical data. One benefit of using SEMs is their capacity to explicitly to account for the temporal sequence that underpins the different events. In our model, we aligned the chronology of the events to investigate how factors connect and affect the abundance of weed throughout the life cycle in arable cropping systems. Using an existing data set from a large-scale field sampling of carabids and weed in arable cropping systems, we analyse the direct and indirect effects of 1) crop rotation; 2) agronomic 
practices; and, 3) the density of carabid beetles on the density of arable weeds growing and stored in the seedbank of arable fields. With this model, we can disentangle part of the complexity of integrated weed management by measuring the specific and combined effects of crop rotation, agronomic practices and seed predation by carabid beetles on weed abundance in arable fields. This quantitative understanding is us eful for developing sustainable weed management strategies that do not compromise crop yield, ensure longterm productivity and minimise the impact on biodiversity and the environment.

\section{Methods}

In our study, we used an extant dataset of ecological surveys in arable fields collected through the Farm Scale Evaluations (FSEs) of genetically modified, herbicide-tolerant (GMHT) crops (Firbank et al., 2003). The FSE field trials were established in 2000 and ran until 2002 to assess the potential impact of adopting genetically-modified crop on arable biodiversity within and surrounding agricultural fields (Hails, 2000; Watkinson et al., 2000). The 256 fields included in the FSE study were carefully selected to provide a representative sample of the British arable farming system (Champion et al., 2003; Firbank et al., 2003). The trials focus on four crops, namely spring-sown maize, springand winter-sown oilseed rape and a spring-sown beet (forage and sugar beet). In the trials, each field was split into two halves with the GMHT variety sown on one side and the conventional variety on the other to contrast the responses observed in genetically modified and conventional crop systems. Here, however, we restricted our analysis to the data collected in the conventional part of the fields. During the FSE field trials, farmers were audited to document the crop management practices, including herbicide treatments used in each field which was based on farmers' decisions and what they considered consistent with cost-effectiveness (Champion et al., 2003; Firbank et al., 2003). In order to document how herbicide usage and concentration varied across crops, we described the list of active ingredients, their concentration and timing of their application (Figure S1).

In each field, data were collected along 12 parallel transects arrange perpendicularlyalong three edges of the fields and ran into the crop. Sampling points were set along each transect and located at 2, 4, 8, 16 and $32 \mathrm{~m}$ from the field margin (see full detail in Firbank et al., 2003). Because we were interested in weed management in the crop field, we excluded data collected near the edge ( 2 and 4 $\mathrm{m}$ ) and focused on sampling points located at 8,16 and $32 \mathrm{~m}$. Data collected in the field trials can be retrieved from NERC Environmental Information Data Centre (Scott et al., 2012a, 2012b, 2012c, 2012d). 


\section{(a) Seedbank}

Seed density contained in the seedbank of e ach field was assessed before the crop was sown $\left(t_{0}\right)$, and before the crop was sown in the following year $\left(t_{1}\right)$. In each field, soil samples were systematically collected along four of the 12 transects before the sowing of the crop to establish a baseline of the seedbank at $t_{0}$ (Heard et al., 2003b). Size and composition of the seedbank were obtained from $1.5 \mathrm{~kg}$ soil samples, taken to a depth of $15 \mathrm{~cm}$ at 2 and $32 \mathrm{~m}$ along four transects per field. Soil samples were weighed and passed through a $10 \mathrm{~mm}$ mesh sieve before being placed in a plastic tray to a depth of $4 \mathrm{~cm}$ and arranged in an unheated glasshouse on capillary matting ke pt moist. Seedlings that emerged from the seed bank samples were identified and removed from the trays for 18 weeks after sample preparation. The following year, soils samples were collected at the same locations, at nearly at the same time of the year, to establish the size and composition of the seedbanks at $\mathrm{t}_{1}$ (Heard et al., 2003b).

\section{(b) Standing weeds}

The composition and density of the above-ground weed community were sampled at two times in the season al ong each of the 12 transects (see Perry et al., 2003). Individual standing weed counts were made once after the sowing of crops and once before harvest after all treatments in $0.25 \times 0.5$ m quadrats set each sampling points along the transect (Heard et al., 2003b). These counts were used to estimate the density (individuals $\mathrm{m}^{-2}$ ) of standing weed observed in each field beyond $8 \mathrm{~m}$ from the edge.

\section{(c) Seed rain}

In each field, a measure of the annually-produced and dispersed seeds was obtained by sampling the seed rain, using four seed traps set at ground level and monitored repeatedly over the growing season (Heard et al., 2003b). Traps of $10 \mathrm{~cm}$ in diameter and $10 \mathrm{~cm}$ high where sunk into the ground at 2 and $32 \mathrm{~m}$ on four transects. Seeds were collected fortnightly, starting afterfirst anthesis of weeds and until crop harvest. The seeds collected over the crop season were pooled, identified to species and classified as 'viable' and 'non-viable' based on their physical attributes (see Heard et al. 2003; Bohan et al. 2005). For our analysis, we quantify the total seed rain as the sum of viable seeds sampled at $32 \mathrm{~m}$ over a year.

\section{(d) Carabid beetle activity-density}

Soil-surface active invertebrates were sampled from pitfall traps ( $6 \mathrm{~cm}$ diameter) placed at 2, 8 and $32 \mathrm{~m}$ along four of the 12 transects. Pitfall traps were open for two-week, on three sampling occasions during the year (Bohan et al., 2005; Brooks et al., 2003). All carabids collected in the pitfall 
trap were counted and identified to species, and then summed across the year to create a year total for analysis. For consistency in the sampling effort and season between spring and winter-sown crops, we only considered carabid counts collected at in July and August for spring crops and April May and June-July for the winter crop, excluding samples collected in September and October in winter-sown oilseed rape (Firbank et al., 2003). For each field, we estimated the year-total activitydensity of granivorous (e.g., Harpalus and Amara spp.) and omnivorous (e.g., Pterostichus and Bembidion spp.) species from the pooled counts sampled in the eight pitfalls (i.e., 8 and $32 \mathrm{~m}$ set along four transects). Because we were interested in estimating the effect of seed predation on weed management, we focused on carabid beetle species that were capable of consuming weed seeds and excluded species that are known to be obligatory carnivores (Luff, 2017).

\section{(e) Carabid predation pressure}

We quantified predation pressure as the number of seeds consumed by the assemblage of carabids present, taking into account carabid seed preferences, the community of seeds present, and carabid energeticrequirements (Pocock et al., 2020). In their work, Pocock et al., (2020) derive a predation pressure index from an inferred carabid-seed food web. In this food web, the interactions were inferred based on species frequency-dependent foraging and size-dependent preferences obtained from the literature (Gendron, 1987; Honek et al., 2013; Petit et al., 2014), and the interaction strengths were calculated by scaling up by carabid density and energetic requirements.

\section{(f) Crop sequence and rotation history}

After the FES trials, a follow-up study was conducted by Bohan et al. (2011b) to document and investigate the effect of crop rotation on weed management. Participating farmers were contacted and asked about the crop history that was grown in for each field, up to nine years before the FSE trials. Farmers provided this information, and the detailed crop sequence was available in 168 fields. From this sequence, we derived two indices to characterise the type of crop and their continuousness (pattern along the sequence) in the cropping systems. We calculated a "cereal index" to capture the frequency and pattern of cereal crops grown in the three years prior to the FSE trials. We also calculated a "winter index" to quantify the frequency and pattern of winter sowing crops grown within the three years. Each index range from 0 to 7 and quantify the pattern in the crop sequence, based on both consecutiveness and recentness of the focal state, where 0 indicates the absence of the focal state (cereal or winter-sown crop) and 7 indicates a continuous sequence over the three years (see Figure S2). 
bioRxiv preprint doi: https://doi.org/10.1101/2020.12.04.411918; this version posted December 4,2020 . The copyright holder for this preprint (which was not certified by peer review) is the author/funder, who has granted bioRxiv a license to display the preprint in perpetuity. It is made available under aCC-BY 4.0 International license.

\section{Structural Equation Model}

In order to obtain a system-based understanding of the interacting components, including the effect of both agronomic and ecological factors, we built our conceptual model around the life cycle of arable weeds growing in conventional cropping systems (Figure 1). In our model, we used theoretical knowledge and results of previous investigations to integrate relationships that hypothesises how the different factors affected each development stages and the dynamics of arable weeds in arable fields. Our model accounts for the temporal sequence of the weed life cycle, as well as the sequence (precedence) of events that underpin specific cropping systems (crop rotation history, field management) and field environment (carabid abundance). In our model, we aligned the chronology to investigate how factors connect and affect the initial seedbank $\left(t_{0}\right)$, the abundance of standing weeds, the seed rain and the activity-density of carabid beetle in the field, their predation pressure and their combined effect on the seedbank in the following year $\left(t_{1}\right)$.

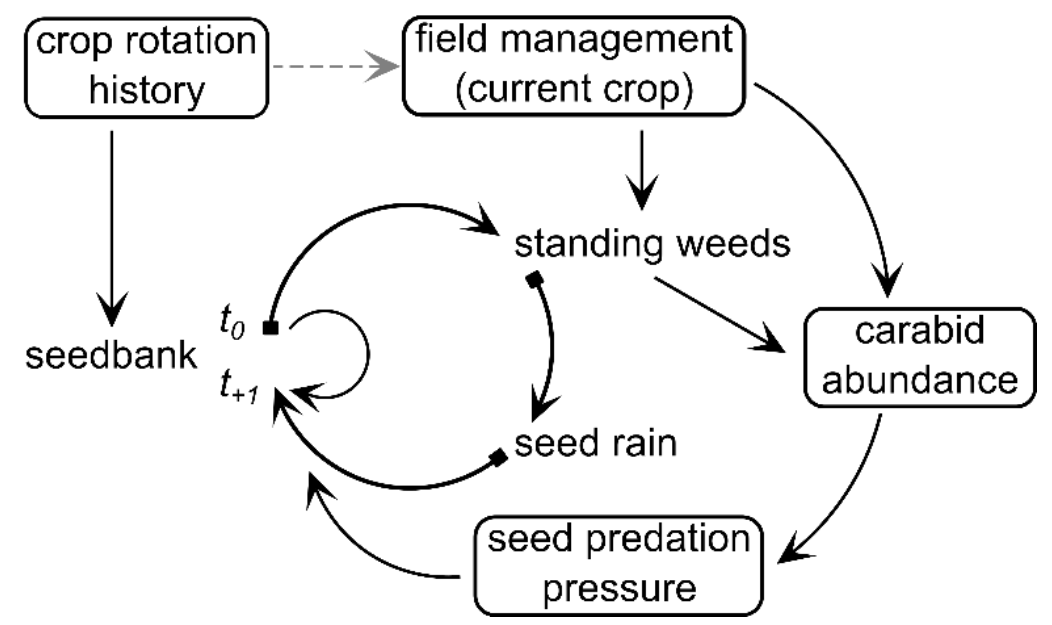

Figure 1 Graphical conceptual model that represent the drivers and their interactions with the life cycle of arable weeds in crop fields. This model integrates both agronomic (crop history and field management) and ecological (seed predation by carabid beetles) components, as well as the chronology (direction) of their direct and indirect effect on the dynamics of arable weeds stored in the seedbank and growing in crop fields.

In our model (Figure 1), we integrated the effect of crop rotation on the seedbank at $t_{0}$ as an effect of past field and crop management (tillage, herbicide option and sowing season). We specifically focused on the crop type (cereal versus non-cereal), and the sowing-season (spring and winter) as 
these two aspects affect management and herbicide regimes, as well as the phenology of the crop cover (Bohan et al., 2011b; Heard et al., 2003a).

Based on our conceptual model (Figure 1), we constructed a Structural Equation Model (SEM). In our SEM, the recent crop history documented in each field was summari sed using their three-year cereal and winter sowing indices (see Section $f$ in Methods above). To account for the potential non-linear effect of crop sequence on the seedbank, we added a quadratic effect between each index and the seedbank $\mathrm{t}_{0}$. The SEM also included the effect of crop management with the variable field management (current crop) which was coded with three binary dummy variables for beet, maize and winter oilseed rape and setting spring oilseed rape as the reference value. With the current crop, we aimed to capture the effect of specific crop and their management on the density of standing weed. We expect the specific sowing season and herbicide usage (Figure S1) associated to the different crops to affect the germination, the establishment and the growth of weeds and thereby influence the density of standing weed, together with the size of the seed pool contained in the seedbank at $t_{0}$. Crop management is not only expected to influence weed but also the activity-density and the composition of carabid beetle foraging in arable fields through its effect on the stability of resting and foraging habitat (Menalled et al., 2007; Trichard et al., 2014). Activity-density of carabid beetle is also expected to be influenced by the density of standing weed density as they partly determine the quality and quantity of resources available to phytophagous species foraging in arable fields (Frei et al., 2019). Finally, we added four effects to predict the abundance of seeds in the seedbank in the following year $\left(t_{1}\right)$. Firstly, the effect of the starting seedbank abundance at $t_{0}$, which accounts for seeds that remain dormant over the cropping season (Mahé et al., 2020). Secondly, the seed rain, which accounts for seeds measured to be shed by the standing weeds. Thirdly, a direct effect linking the standing weed with the seedbank $t_{1}$, which accounts for seeds shed by standing weeds, but not captured in the seed rain sample. This structural part (direct effect) was added after examination of the remaining covariance when the model only included the effect of the seed rain, i.e. the indirect link between standing weed and seedbank $t_{1}$. Fourthly, the effect of carabid beetles on the seedbank at $t_{1}$ by including the predation pressure index derived from the inferred carabid-seed food web in each field (see details in Pocock et al., 2020). With this last relationship, we accounts for the effectiveness of carabids in regulating arable weeds, based on their dietary preference and calorific requirement which are expected to have important implication in carabid seed consumption and contribution to weed management (Gaba et al., 2019; Honek et al., 2013; Petit et al., 2014). 
We specified the SEM and the relationships between the endogenous and exogenous variable as follow:

$$
\begin{aligned}
& \text { cereal index }+ \text { cereal index }{ }^{2}+\text { winter index }+ \text { winter } \text { index }^{2} \rightarrow \log _{10}\left(S B t_{0}\right) \\
& \log _{10}\left(S B t_{0}\right)+\text { beet }+ \text { maize }+ \text { winter } O S R \rightarrow \log _{10}(S W) \\
& \log _{10}(S W) \rightarrow \log _{10}(S R) \\
& \log _{10}(S W)+\text { beet }+ \text { maize }+ \text { winter } O S R \rightarrow \log _{10}(C A) \\
& \log _{10}(C A) \rightarrow \log _{10}(P P) \\
& \log _{10}\left(S B t_{0}\right)+\log _{10}(S W)+\log _{10}(S R)+\log _{10}(P P) \rightarrow \log _{10}\left(S B t_{1}\right)
\end{aligned}
$$

where $S B$ is weed count in the seedbank, SWin the standing weed, $S R$ in the seed rain, $C A$ is the active-density of carabid beetles, $P P$ the predation pressure and $O S R$ stand for oilseed rape.

\section{Statistical modelling}

Fitting complex SEMs can be challenging and it requires large data sets to reach convergence and produce reliable confidence intervals. However, recent computational advances have led to the development of Bayesian approaches for SEMs (Merkle et al., 2020) that allow for the fitting of complex models because they address issues of non-convergence and improve estimations of parameter confidence intervals (Smid et al., 2020). We, therefore, fitted our SEM within a Bayesian framework, using the MCMC samplerStan 2.21-0 (Carpenter et al., 2017), in combination with the $R$ packages lavaan 0.6-7 (Rosseel, 2012) and blavaan 0.3-10 (Merkle and Rosseel, 2018). The estimates for the Bayesian SEM were derived from four chains with 10,000 samples, after 5,000 burn-in iterations and a thinning factor of one. When fitting our model, we used weakly informative prior for the beta parameters (regression coefficient), using a normal distribution with mean 0 and standard deviation of five. This prior was preferred to the default normal $(0,10)$ available in blavaan (Merkle and Rosseel, 2018) because we used the $\log _{10}$ transformation for each variable derived from counts (seedbank, standing weed, seed rain, carabid activity-density, and predation pressure). Therefore, coefficients are expressed on a log-log scale and must be interpreted as expected proportional differences per proportional change (i.e. per cent of the difference of $y$ for a per cent change in $x$ ). Note however that rotation indices and crops were not log-transformed, and the coefficients to the transformed count must be interpreted as multiplicative differences (i.e., $y=10^{\text {coefficient }}$ for a change of 1 in $x$ ). Because our priors contain little information, our posterior estimates are dominated by the information available in the data. We assessed the MCMC chains convergence through visual observation and the potential scale reduction factor (Rhat $\approx 1$ ). We estimated the validity of our conceptual model from the overall fit judged from the posterior predictive $p$-value ( $p p p)$. For each 
endogenous variables (dependent), we calculated the proportion of variance explained from the Bayesian $R^{2}$ derived from the standardised variance estimates. Based on the results of our SEM, we implemented a multivariate response model (Path model) within a Bayesian framework, using the package brms 2.13-5 (Bürkner, 2018) to define our model with the same prior as specified in the SEM, normal $(0,5)$, with four MCMC chains, 10,000 samples and 5,000 burn-in iterations and a thinning factor of one. From the posterior samples, we estimated the conditional effects for each local model included in the SEM (Figure 1).

\section{Results}

The system framework provided by the structural equation model(SEM) was useful to integrate and identify the effect sizes of the different drivers shaping the structuring the abundance and dynamics of arable weeds in cropping systems (Figure 2). Our SEM, build around the life cycle of arable weeds, enabled us to integrate both agronomic and ecological factors and explained 43 percent of the variation observed in the density of weed contained in the seedbank after one crop season (Table 1). While past field cropping history explained five percent of the variance of contained in the seedbank at $t_{0}$, when we added the components of the weed life cycle, crop management and the regulatory effect provided by carabid beetles, the predictive power of our model was substantially increased, with $\mathrm{R}^{2}$ for local models ranging from 0.05 to 0.63 (Table 1 ).

In our study, we focus on the impact of the structure of past crop rotations (crop type and seasonality), the effect of crop management crop and the influence of foraging ground beetles feeding on weed seeds. Our SEM enabled us to account for the temporal aspect of each relationship, identifying both the direct and indirect effects of the drivers and showing how regulation services provided by carabid beetle are intertwined within the dynamics of the weed and cropping system (Figure 2). Our model shows the contribution of the different components of the system that regulate the abundance of seeds growing in the field and accumulating in the seedbank over time. Interestingly, our results suggest that predation pressure provided by carabid beetles contribute significantly to reduce the accumulation and the size of the seedbank, having nearly the same effect size, but in the opposite direction as the seed rain (Table 1). 


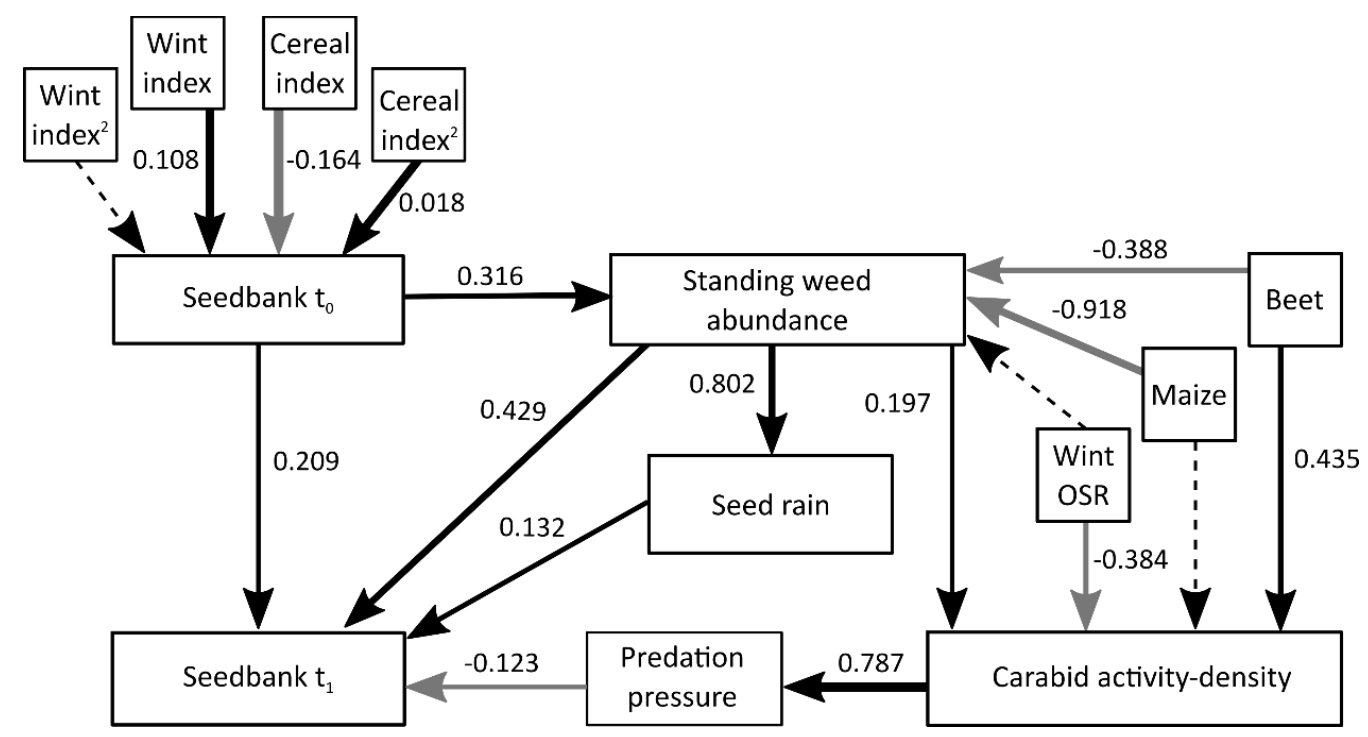

Figure 2 Summary of the structural equation model (SEM), with unstandardised estimates of the effects of crop rotation, field management and predation pressure of seed-eating carabid beetles on the density of weeds growing in the fields and stored in the seedbanks at $t_{0}$ and $t_{1}$. Solid arrows represent significant effects, black for positive and grey for negative, and dashed arrows display nonsignificant effects. The thickness of each arrow is relative to the standardised effect size. The global model provides an acceptable fit to the data (Bayesian fit: $n=168$, PPP $=0.086$ ).

Although the crop history (rotation) defined by the cereal and winter-sowing indices had a relatively low explanatory power, the model shows that the abundance of seed contained in the seedbank at $t_{0}$ was significantly lower in fields where recent crop sequence had non-consecutive cereal (including a break crop) (Figure 3a). The quadratic effect of the cereal component of the rotation shows its importance for regulating the size of seedbank over time, as well as the density the weed growing in the field and competing with crop. Interestingly, fields that had recent winter sowing crop (winter index level 3 and 4) tended to have slightly larger seedbank. Nevertheless, this effect was relatively small and it is unclear if this effect persists as winter crops are sown over multiple years (Figure 3b) (Table 1). 
Table 1 Detailed SEM estimates and $95 \%$ credible confidence intervals and $R^{2}$ for each endogenous variables. The SEM was fitted with Stan MCMC sampler, using 10,000 samples and 5,000 burn-in iterations. The global model offers an acceptable fit to the data (Bayesian fit: $n=168, p p p=0.086$ ).

\begin{tabular}{|c|c|c|c|c|}
\hline \multirow[t]{2}{*}{ Regression models } & \multirow[b]{2}{*}{ Estimate } & \multicolumn{2}{|c|}{ Credible Confidence Interval (95\%) } & \multirow{2}{*}{$\begin{array}{c}\text { Standardised } \\
\text { Estimate }\end{array}$} \\
\hline & & lower & upper & \\
\hline \multicolumn{5}{|l|}{ Seedbank to $\left(R^{2}=0.05\right)$} \\
\hline Cereal index & -0.164 & -0.288 & -0.039 & -0.794 \\
\hline Cereal index ${ }^{2}$ & 0.018 & 0.002 & 0.034 & 0.679 \\
\hline Winter index & 0.108 & 0.002 & 0.217 & 0.635 \\
\hline Winter index ${ }^{2}$ & -0.014 & -0.030 & 0.001 & -0.581 \\
\hline \multicolumn{5}{|l|}{ Standing weed $\left(R^{2}=0.32\right)$} \\
\hline Seedbank to & 0.316 & 0.155 & 0.479 & 0.251 \\
\hline Maize & -0.918 & -1.165 & -0.674 & -0.534 \\
\hline Beet & -0.388 & -0.583 & -0.195 & -0.307 \\
\hline Winter OSR & -0.125 & -0.327 & 0.075 & -0.094 \\
\hline \multicolumn{5}{|l|}{ Seed Rain $\left(R^{2}=0.23\right)$} \\
\hline Standing weed & 0.802 & 0.574 & 1.031 & 0.481 \\
\hline \multicolumn{5}{|c|}{ Carabid activity-density $\left(\mathrm{R}^{2}=0.22\right)$} \\
\hline Maize & -0.122 & -0.468 & 0.225 & -0.060 \\
\hline Beet & 0.435 & 0.181 & 0.685 & 0.291 \\
\hline Winter OSR & -0.384 & -0.633 & -0.133 & -0.244 \\
\hline Standing weed & 0.197 & 0.010 & 0.382 & 0.166 \\
\hline \multicolumn{5}{|c|}{ Predation pressure $\left(R^{2}=0.63\right)$} \\
\hline Carabid dens. & 0.787 & 0.694 & 0.881 & 0.792 \\
\hline \multicolumn{5}{|l|}{ Seedbank $t_{1}\left(R^{2}=0.43\right)$} \\
\hline Seedbank $t_{0}$ & 0.209 & 0.061 & 0.356 & 0.171 \\
\hline Seed rain & 0.132 & 0.056 & 0.209 & 0.228 \\
\hline Standing weed & 0.429 & 0.298 & 0.561 & 0.444 \\
\hline Predation pressure & -0.123 & -0.221 & -0.024 & -0.150 \\
\hline
\end{tabular}


a)

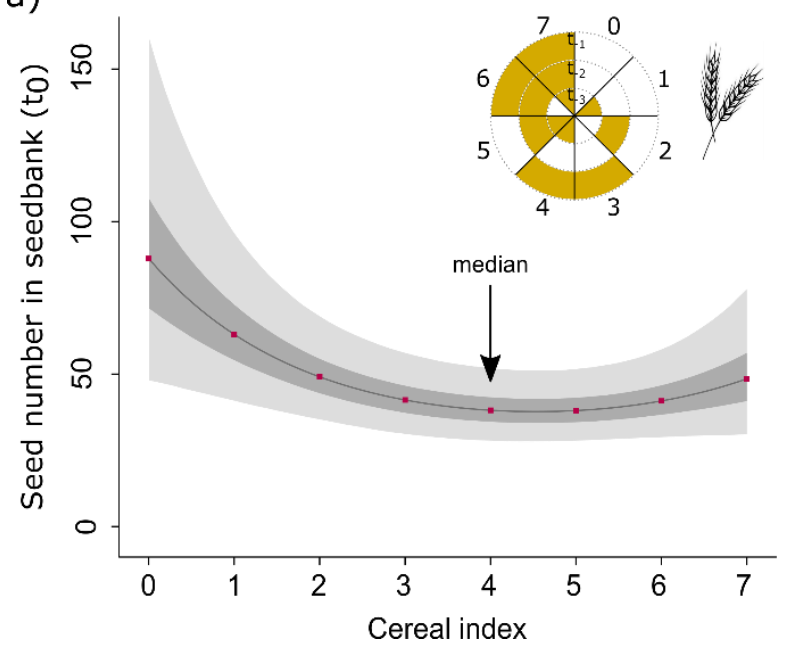

b)

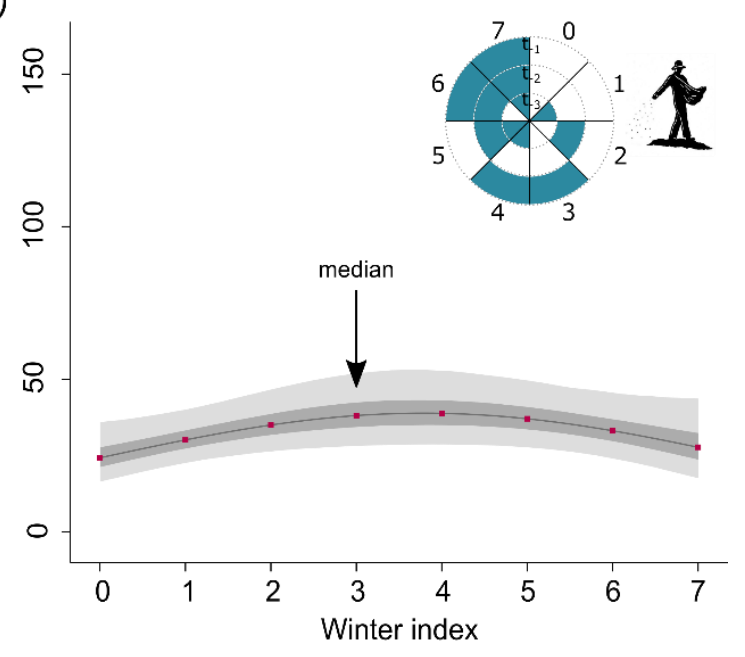

Figure 3 Conditional effects for $a$ ) cereal and $b$ ) winter sowing crop on the number of seeds in the seed bank at $t_{0}$. Conditional effects were derived from a Bayesian multivariate response model with seed density $\log _{10}$ transformed and where all other predictor variables set to their mean. Indices are derived from the 3-year crop history (three years before $t_{0}$ ) and range from 0 to 7 , where 0 indicate the absence of cereal or winter sowing and 7 three consecutive years of cereal or winter sowing (Figure S2). The 50\% and $95 \%$ credible intervals are depicted by the dark and light grey areas around the point estimates. For each index, we identified the median value of the index with an arrow.

Identity of the crop grown in arable fields and the associated management practices, including herbicide regimes (Figure S1), and potentially crop-weed competition had a substantial effect on the density of weed growing in the field, with maize and beet having markedly fewer weeds than oilseed rape (Figure 4a). Fields with winter-sown oilseed rape tended to have a lower density of weeds than spring-sown oilseed rape (Figure 4a). This difference suggests that sowing season and the phenology of the crop (canopy development) impact weed growth through its effect on weed-crop competition. Although the density of standing weeds growing in crop field had a positive effect on the activity-density of carabid beetles, it was clear that other factors influenced the density of carabids because their abundance was substantially higher in fields growing beet, even though this crop did not have the highest density of arable weeds (Figure 4). 
a)

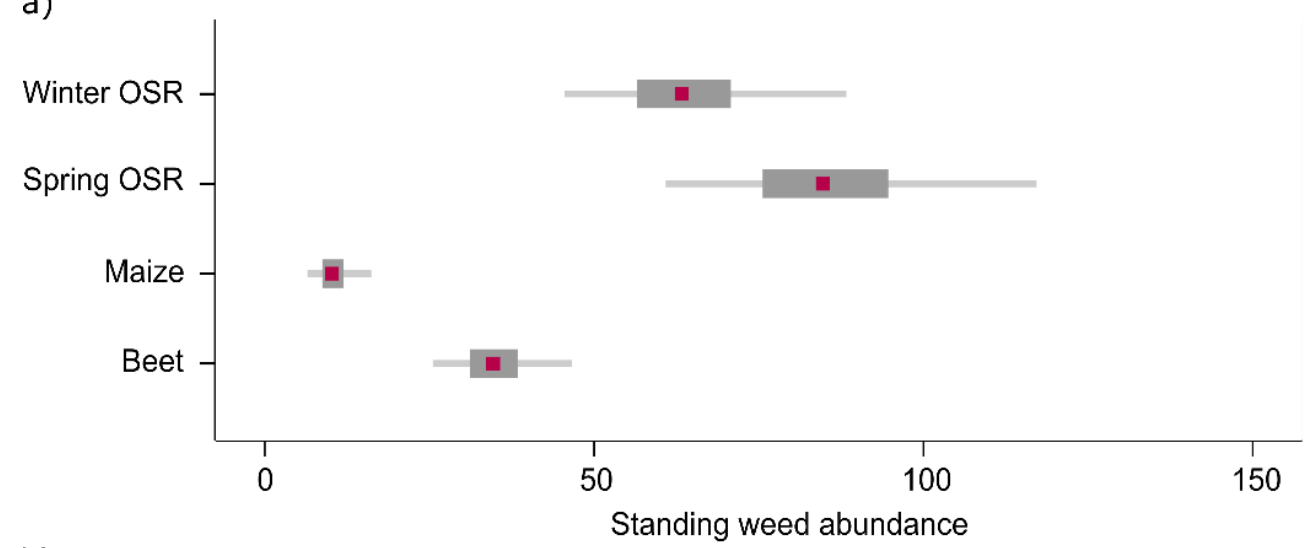

b)

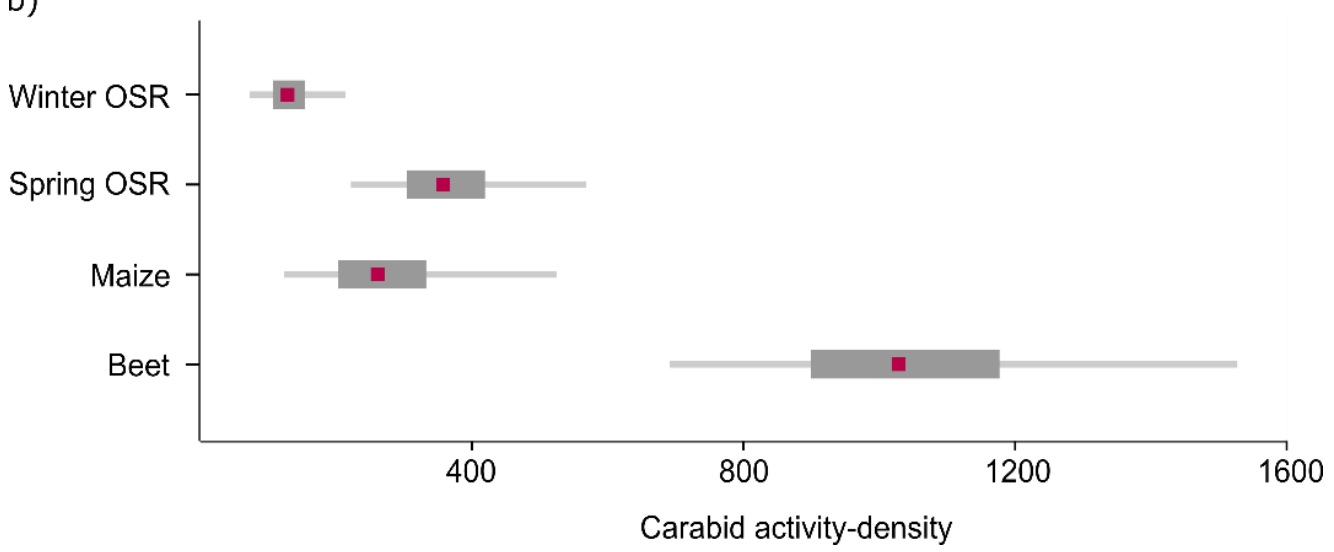

Figure 4 Conditional effect of crop sown at $t_{0}$ on a) standing weed abundance and b) carabid activitydensity. Conditional effects were calculated with all other predictor variables set to their mean. The $50 \%$ and $95 \%$ credible intervals are depicted by the dark and light grey areas around the point estimates. Estimates are derived from a Bayesian multivariate response model, with the count of standing weed abundance and carabid-activity density $\log _{10}$-transformed. OSR = oilseed rape.

Overall, our models show that the density of standing weeds growing in the field had the largest effect on the size of the seedbank in the following year (Figure 5b). However, our results also show that the size of the seedbank is determined, at least partly, by the activity of seed-eating carabids beetles (Figure $5 c$ ). This suggests that when crop rotation are carefully designed, and in-field conditions are managed to increase the density and the predation pressure exerted by carabid beetles, their combined effects can help regulate the size of the seedbank and over time help managing the density of weeds growing in the arable fields (Figure 5). The increase of the activity density of seed-eating carabid beetles observed when the weeds density in crop field increases suggest that the regulation service provided by these invertebrates is likely to vary with the need for weed management (Figure 2). 
a)

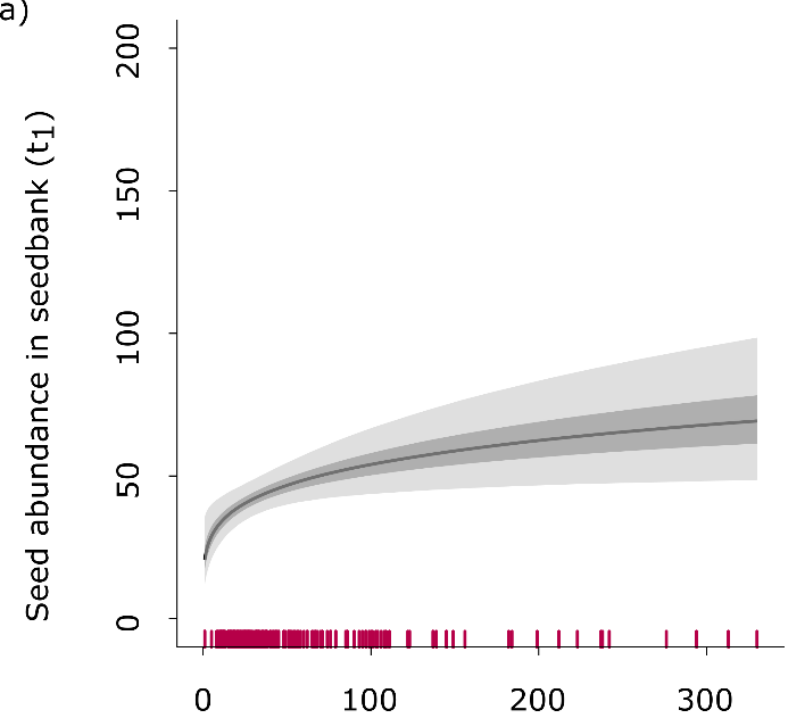

Seed abundance in seedbank ( $\left.\mathrm{t}_{0}\right)$

c)

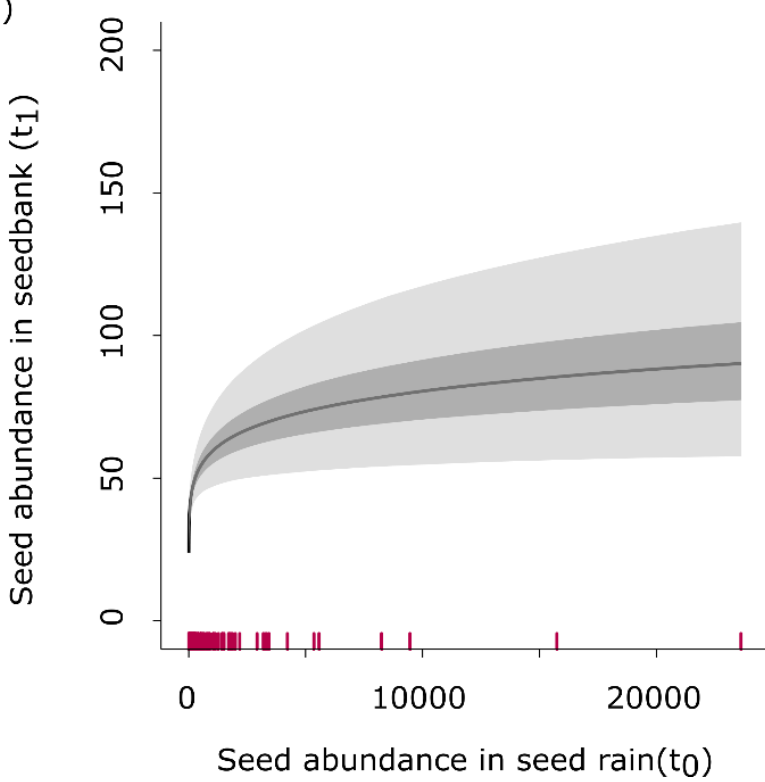

b)

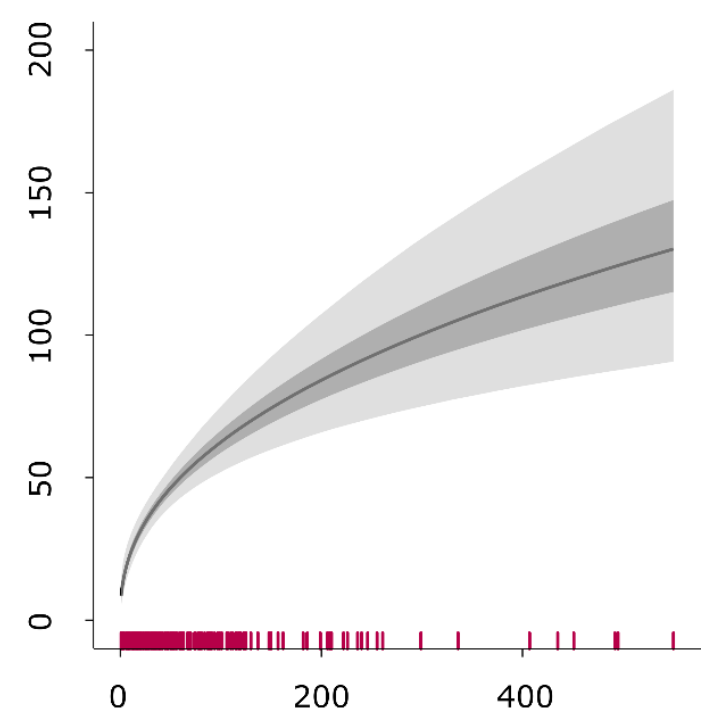

Standing weed density ( $\left.\mathrm{t}_{0}\right)$

d)

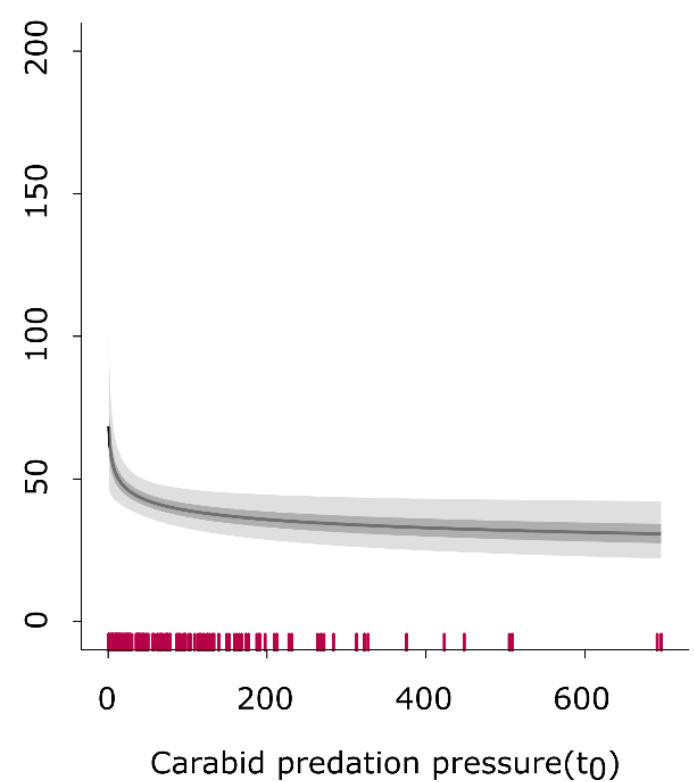

Figure 5 Conditional effects of a) the effect of seedbank density at $t_{0}, b$ ) standing weed density per square meter at $t_{0}, c$ ) the number of seed in seed rain on seedbank density at $t_{+1}$ and $d$ ) the predation pressure of seed-eating carabid on seed density in the seedbank at $t_{1}$. Conditional effects were calculated with all other predictor variables set to their mean. The $50 \%$ and $95 \%$ credible intervals are depicted by the dark and light grey areas around the mean estimates. Estimates are derived from a Bayesian multivariate response model, with count variables being $\log _{10}$ transformed. 


\section{Discussion}

Sustainable weed management is essential for maintaining the productivity of cropping system while minimising the negative impact on the environment. Development of strategies that integrate both agronomic and ecological processes into cropping systems will contribute to ensure food security and support essential biodiversity that agroecosystems depend on. In this study, we clearly show that agronomic practices associated to cropping systems and the regulation services provided by carabid beetles are intertwined and together influence the density and the dynamics of weeds stored and growing in arable fields. Such understanding can provide new perspectives that will help farmers and agronomists integrate nature-based solutions to maintain high yield while reducing the economic and environmental cost of weed management.

Integrated weed management applied in conventional agricultural systems has al ways aimed at combining multiple approaches to increase the efficiency of weed management. However, the complexity and the level of integration of ecological processes regulating the density and controlling for weed outbreaks is often very limited (MacLaren et al., 2020; Petit et al., 2018). Because seeds in the seedbank are buried in the soil and remain invisible to farmers, it is challenging to explicitly accounted for in weed management plans. This lack of information has probably contributed to the fact that weed management is mainly applied responsively where the density of arable weeds is controlled through herbicides application. This approach is effective and influences the density of weed accumulating in the seedbank, but because it does not explicitly account for the regulation services provided by biological agents such as seed-eating carabids, farmers cannot fully integrate the cost and benefits of such approaches. By systematically accounting for the effect of crop rotation and seed predation on the seedbank, and how these effects cascade across the different life stages of arable weeds, we can reveal areas in the weed management plans where synergy can be created and where tradeoffs must be carefully considered (Mézière et al., 2015). Such information is difficult to derive from independent analysis accounting for the action of each aspect separately.

We show that farmers can actively reduce the abundance of weed contained in the seedbank by managing the frequency and consecutiveness of cereal crops and, but to a lesser extent, by varying the sowing season. This result confirms the well-known benefits of including 'break crops' in rotation, changing the selective pressure applied on the weed community and thereby regulating the demography of different species or type of arable weeds (monocot versus dicot) (Derksen et al., 2002). By changing the sowing season, producers are not only affecting the timing of soil disturbance regimes (tillage and drilling), but also the phenology of the crop cover and thereby changing cropweed competition (Colbach et al., 2014). The competitive of taller crops suppress the germination 
and growth of weeds, but also reduce reproduction success and the number of seeds re-entering the seedbank.

Weed regulation through the effect of carabid beetles has been documented in many studies, and our results confirm how these biological agents can contribute and strengthen the efficiency of integrated weed management approaches (Bohan et al., 2011a; Kulkarni et al., 2015). Because field management and the density of standing weeds in arable fields influence the number of seed-eating carabid beetles foraging in the field, optimal weed management would aim at regulating rather than eradicating weeds. This would allowsupporting effective level of predation pressure in the field in order to limit the number of seed re-entering the seedbank. Weed regulation through the action of natural predators not only reduces the number of weeds in the seedbank but can also reduce the use of synthetic herbicides and the risk of evolution of herbicide-resistance. Although carabid beetles do have preferences in their seed consumption (Honek et al., 2007; Petit et al., 2014), carabid diet is relatively broad and largely driven by seed:carabid size (Pocock et al. 2020). Therefore, the regulation service provided by carabid beetles is likely to increase taxonomic and functional diversity and control the dominance of highly competitive weeds.

When considered together, appropriate crop rotations and effective seed-predation provided by seed-eating beetles provide tools additional to synthetic herbicides to manage weeds in arable fields and their effect on crop yield. By using a system framework that accounts for the effect of different drivers regulating the size and the composition of weed communities, we give farmers the means to improve the sustainability and resilience of agroecosystems. Weed management strategies that integrate and connect agronomic and ecological regulation components can reduce the reliance on synthetic herbicides and promote the long-term provision of highly valuable ecosystem services to secure the future of food production systems. 


\section{Data accessibility}

The FSE data, including the farm management data, are available from the NERC Environmental Information Data Centre (https://catalogue.ceh.ac.uk/documents/876358e4-62f7-4386-99e17d3eac223e03).

\section{CRediT author statement}

RS: Conceptualisation, Methodology, Data Curation, Formal Analysis Writing - Original Draft, Visualisation, Writing - Review and Editing; DAB: Funding acquisition, Project administration, Conceptualisation, Methodology, Writing - Review and Editing; MJOP: Funding acquisition, Project administration, Conceptualisation, Methodology, Writing - Review and Editing

\section{Acknowledgments}

RS and MJOP were funded by Defra (contract SCF0313). DAB was funded by the Agence Nationale de la Recherche (ANR). This work is an output of the PREAR project (Predicting and enhancing the Resilience of European Agro-ecosystems to environmental change using crop Rotations), a partnership between INRA, UKCEH, University of Copenhagen and Aarhus, Solagro and Szent István University. The PREAR project was funded as part of the European FACCE SURPLUS (sustainable and resilient agriculture for food and non-food systems) and the ERA-NET co-fund scheme under Horizon 2020 programme formed in collaboration between the European Commission and a partnership of 15 countries in the frame of the Joint Programming Initiative on Agriculture, Food Security and Climate Change (FACCE-JPI). 


\section{References}

Barré, K., Le Viol, I., Julliard, R., Kerbiriou, C., 2018. Weed control method drives conservation tillage efficiency on farmland breeding birds. Agriculture, Ecosystems \& Environment 256, 74-81. https://doi.org/10.1016/j.agee.2018.01.004

Bohan, D.A., Boffey, C.W.H., Brooks, D.R., Clark, S.J., Dewar, A.M., Firbank, L.G., Haughton, A.J., Hawes, C., Heard, M.S., May, M.J., Osborne, J.L., Perry, J.N., Rothery, P., Roy, D.B., Scott, R.J., Squire, G.R., Woiwod, I.P., Champion, G.T., 2005. Effects on weed and invertebrate abundance and diversity of herbicide management in genetically modified herbicide-tolerant winter-sown oilseed rape. Proceedings of the Royal Society B: Biological Sciences 272, 463-474.

https://doi.org/10.1098/rspb.2004.3049

Bohan, D.A., Boursault, A., Brooks, D.R., Petit, S., 2011a. National-scale regulation of the weed seedbank by carabid predators. Journal of Applied Ecology 48, 888-898.

https://doi.org/10.1111/j.1365-2664.2011.02008.x

Bohan, D.A., Powers, S.J., Champion, G., Haughton, A.J., Hawes, C., Squire, G., Cussans, J., Mertens, S.K., 2011b. Modelling rotations: can crop sequences explain arable weed seedbank abundance? Weed Research 51, 422-432. https://doi.org/10.1111/j.1365-3180.2011.00860.x

Bommarco, R., Kleijn, D., Potts, S.G., 2013. Ecological intensification: harnessing ecosystem services for food security. Trends in Ecology \& Evolution 28, 230-238.

https://doi.org/10.1016/j.tree.2012.10.012

Bretagnolle, V., Gaba, S., 2015. Weeds for bees? A review. Agron. Sustain. Dev. 35, 891-909. https://doi.org/10.1007/s13593-015-0302-5

Brooks, D.R., Bohan, D.A., Champion, G.T., Haughton, A.J., Hawes, C., Heard, M.S., Clark, S.J., Dewar, A.M., Firbank, L.G., Perry, J.N., Rothery, P., Scott, R.J., Woiwod, I.P., Birchall, C., Skellern, M.P., Walker, J.H., Baker, P., Bell, D., Browne, E.L., Dewar, A.J.G., Fairfax, C.M., Garner, B.H., Haylock, L.A., Horne, S.L., Hulmes, S.E., Mason, N.S., Norton, L.R., Nuttall, P., Randle, Z., Rossall, M.J., Sands, R.J.N., Singer, E.J., Walker, M.J., 2003. Invertebrate responses to the management of genetically modified herbicide-tolerant and conventional spring crops. I. Soil-surface-active invertebrates. Philosophical Transactions of the Royal Society B: Biological Sciences 358, 1847-1862.

https://doi.org/10.1098/rstb.2003.1407

Bürkner, P.-C., 2018. Advanced Bayesian Multilevel Modeling with the R Package brms. The R Journal 10, 395. https://doi.org/10.32614/RJ-2018-017

Carbonne, B., Petit, S., Neidel, V., Foffova, H., Daouti, E., Frei, B., Skuhrovec, J., Řezáč, M., Saska, P., Wallinger, C., Traugott, M., Bohan, D.A., 2020. The resilience of weed seedbank regulation by carabid beetles, at continental scales, to alternative prey. Scientific Reports 10, 19315. https://doi.org/10.1038/s41598-020-76305-w

Carpenter, B., Gelman, A., Hoffman, M.D., Lee, D., Goodrich, B., Betancourt, M., Brubaker, M., Guo, J., Li, P., Riddell, A., 2017. Stan : A Probabilistic Programming Language. Journal of Statistical Software 76. https://doi.org/10.18637/jss.v076.i01

Champion, G.T., May, M.J., Bennett, S., Brooks, D.R., Clark, S.J., Daniels, R.E., Firbank, L.G., Haughton, A.J., Hawes, C., Heard, M.S., Perry, J.N., Randle, Z., Rossall, M.J., Rothery, P., Skellern, M.P., Scott, R.J., Squire, G.R., Thomas, M.R., 2003. Crop management and agronomic context of the Farm Scale 
Evaluations of genetically modified herbicide-tolerant crops. Philosophical Transactions of the Royal Society B: Biological Sciences 358, 1801-1818. https://doi.org/10.1098/rstb.2003.1405

Colbach, N., Collard, A., Guyot, S.H.M., Mézière, D., Munier-Jolain, N., 2014. Assessing innovative sowing patterns for integrated weed management with a 3D crop:weed competition model. European Journal of Agronomy 53, 74-89. https://doi.org/10.1016/j.eja.2013.09.019

Cross, P., Edwards-Jones, G., 2011. Variation in pesticide hazard from arable crop production in Great Britain from 1992 to 2008: An extended time-series analysis. Crop Protection 30, 1579-1585. https://doi.org/10.1016/j.cropro.2011.08.003

Derksen, D.A., Anderson, R.L., Blackshaw, R.E., Maxwell, B., 2002. Weed Dynamics and Management Strategies for Cropping Systems in the Northern Great Plains. AGRONOMY JOURNAL 94, 12.

Deroulers, P., Bretagnolle, V., 2019. The consumption pattern of 28 species of carabid beetles (Carabidae) to a weed seed, Viola arvensis. Bulletin of Entomological Research 109, 229-235. https://doi.org/10.1017/S0007485318000457

FAO, 2020. The pesticides use database.

Firbank, L.G., Heard, M.S., Woiwod, I.P., Hawes, C., Haughton, A.J., Champion, G.T., Scott, R.J., Hill, M.O., Dewar, A.M., Squire, G.R., May, M.J., Brooks, D.R., Bohan, D.A., Daniels, R.E., Osborne, J.L., Roy, D.B., Black, H.I.J., Rothery, P., Perry, J.N., 2003. An introduction to the Farm-Scale Evaluations of genetically modified herbicide-tolerant crops. Journal of Applied Ecology 40, 2-16.

https://doi.org/10.1046/j.1365-2664.2003.00787.x

Freemark, K., Boutin, C., 1995. Impacts of agricultural herbicide use on terrestrial wildlife in temperate landscapes: A review with special reference to North America. Agriculture, Ecosystems \& Environment 52, 67-91. https://doi.org/10.1016/0167-8809(94)00534-L

Frei, B., Guenay, Y., Bohan, D.A., Traugott, M., Wallinger, C., 2019. Molecular analysis indicates high levels of carabid weed seed consumption in cereal fields across Central Europe. J Pest Sci 92, 935942. https://doi.org/10.1007/s10340-019-01109-5

Gaba, S., Deroulers, P., Bretagnolle, F., Bretagnolle, V., 2019. Lipid content drives weed seed consumption by ground beetles (Coleopterea, Carabidae) within the smallest seeds. Weed Research 59, 170-179. https://doi.org/10.1111/wre.12354

Gendron, R.P., 1987. Models and Mechanisms of Frequency-Dependent Predation. The American Naturalist 130, 603-623. https://doi.org/10.1086/284733

Gibbons, D.W., Bohan, D.A., Rothery, P., Stuart, R.C., Haughton, A.J., Scott, R.J., Wilson, J.D., Perry, J.N., Clark, S.J., Dawson, R.J.G., Firbank, L.G., 2006. Weed seed resources for birds i n fields with contrasting conventional and genetically modified herbicide-tolerant crops. ProcBiol Sci 273, 19211928. https://doi.org/10.1098/rspb.2006.3522

Hails, R.S., 2000. Genetically modified plants - the debate continues. Trends in Ecology \& Evolution 15, 14-18. https://doi.org/10.1016/S0169-5347(99)01751-6

Hawes, C., Begg, G.S., Iannetta, P.P.M., Karley, A.J., Squire, G.R., 2016. A whole-systems approach for assessing measures to improve arable ecosystem sustainability. Ecosystem Health and Sustain ability 2, e01252. https://doi.org/10.1002/ehs2.1252 
Heard, M.S., Hawes, C., Champion, G.T., Clark, S.J., Firbank, L.G., Haughton, A.J., Parish, A.M., Perry, J.N., Rothery, P., Roy, D.B., Scott, R.J., Skellern, M.P., Squire, G. R., Hill, M.O., 2003a. Weeds in fields with contrasting conventional and genetically modified herbicide-tolerant crops. II. Effects on individual species. Philosophical Transactions of the Royal Society B: Biological Sciences 358, 18331846. https://doi.org/10.1098/rstb.2003.1401

Heard, M.S., Hawes, C., Champion, G.T., Clark, S.J., Firbank, L.G., Haughton, A.J., Parish, A.M., Perry, J.N., Rothery, P., Scott, R.J., Skellern, M.P., Squire, G. R., Hill, M.O., 2003b. Weeds in fields with contrasting conventional and genetically modified herbicide-tolerant crops. I. Effects on abundance and diversity. Philosophical Transactions of the Royal Society B: Biological Sciences 358, 1819-1832. https://doi.org/10.1098/rstb.2003.1402

Hicks, H.L., Comont, D., Coutts, S.R., Crook, L., Hull, R., Norris, K., Neve, P., Childs, D.Z., Freckleton, R.P., 2018. The factors driving evolved herbicide resistance at a national scale. Nature Ecology \& Evolution 2, 529-536. https://doi.org/10.1038/s41559-018-0470-1

Honek, A., Martinkova, Z., Jarosik, V., 2013. Ground beetles (Carabidae) as seed predators. EJE 100, 531-544. https://doi.org/10.14411/eje.2003.081

Honek, A., Martinkova, Z., Saska, P., Pekar, S., 2007. Size and taxonomic constraints determine the seed preferences of Carabidae (Coleoptera). Basic and Applied Ecology 8, 343-353.

https://doi.org/10.1016/j.baae.2006.07.002

Kraus, E.C., Stout, M.J., 2019. Direct and Indirect Effects of Herbicides on Insect Herbivores in Rice, Oryza sativa. Sci Rep 9. https://doi.org/10.1038/s41598-019-43361-w

Kulkarni, S.S., Dosdall, L.M., Willenborg, C.J., 2015. The Role of Ground Beetles (Coleoptera: Carabidae) in Weed Seed Consumption: A Review. Weed Science 63, 355-376. https://doi.org/10.1614/WS-D-14-00067.1

Lami, F., Boscutti, F., Masin, R., Sigura, M., Marini, L., 2020. Seed predation intensity and stability in agro-ecosystems: Role of predator diversity and soil disturbance. Agriculture, Ecosystems \& Environment 288, 106720. https://doi.org/10.1016/j.agee.2019.106720

Luff, M.L., 2017. The Carabidae (ground Beetles) of Britain and Ireland Handbooks for the identification of British insects, Royal Entomological Society of London, 2nd, illustrated ed, RES Handbooks for the Identification of British Insects. Royal Entomological Society.

MacLaren, C., Storkey, J., Menegat, A., Metcalfe, H., Dehnen-Schmutz, K., 2020. An ecological future for weed science to sustain crop production and the environment. A review. Agron. Sustain. Dev. 40, 24. https://doi.org/10.1007/s13593-020-00631-6

Mahé, I., Cordeau, S., Bohan, D.A., Derrouch, D., Dessaint, F., Millot, D., Chauvel, B., 2020. Soil seedbank: Old methods for new challenges in agroecology? Annals of Applied Biology early view. https://doi.org/10.1111/aab.12619

Menalled, F.D., Smith, R.G., Dauer, J.T., Fox, T.B., 2007. Impact of agricultural management on carabid communities and weed seed predation. Agriculture, Ecosystems \& Environment 118, 49-54. https://doi.org/10.1016/j.agee.2006.04.011

Merkle, E.C., Fitzsimmons, E., Uanhoro, J., Goodrich, B., 2020. Efficient Bayesian Structural Equation Modeling in Stan. arXiv:2008.07733 [stat]. 
Merkle, E.C., Rosseel, Y., 2018. blavaan: Bayesian Structural Equation Models via Parameter Expansion 85. https://doi.org/10.18637/jss.v085.i04

Mézière, D., Petit, S., Granger, S., Biju-Duval, L., Colbach, N., 2015. Developing a set of simulationbased indicators to assess harmfulness and contribution to biodiversity of weed communities in cropping systems. Ecological Indicators 48, 157-170. https://doi.org/10.1016/j.ecolind.2014.07.028

Moss, B., 2008. Water pollution by agriculture. Philosophical Transactions of the Royal Society B: Biological Sciences 363, 659-666. https://doi.org/10.1098/rstb.2007.2176

Murphy, S.D., Clements, D.R., Belaoussoff, S., Kevan, P.G., Swanton, C.J., 2006. Promoti on of weed species diversity and reduction of weed seedbanks with conservation tillage and crop rotation. Weed Science 54, 69-77. https://doi.org/10.1614/WS-04-125R1.1

Perry, J.N., Rothery, P., Clark, S.J., Heard, M.S., Hawes, C., 2003. Design, analysis an d statistical power of the Farm-Scale Evaluations of genetically modified herbicide-tolerant crops. Journal of Applied Ecology 40, 17-31.

Petit, S., Boursault, A., Bohan, D.A., 2014. Weed seed choice by carabid beetles (Coleoptera: Carabidae): Linking field measurements with laboratory diet assessments. EJE 111, 615-620. https://doi.org/10.14411/eje.2014.086

Petit, S., Cordeau, S., Chauvel, B., Bohan, D., Guillemin, J.-P., Steinberg, C., 2018. Biodiversity-based options for arable weed management. A review. Agron. Sustain. Dev. 38, 48.

https://doi.org/10.1007/s13593-018-0525-3

Petit, S., Trichard, A., Biju-Duval, L., McLaughlin, Ó.B., Bohan, D.A., 2017. Interactions between conservation agricultural practice and landscape composition promote weed seed predat ion by invertebrates. Agriculture, Ecosystems \& Environment 240, 45-53.

https://doi.org/10.1016/j.agee.2017.02.014

Pleasants, J., 2017. Milkweed restoration in the Midwest for monarch butterfly recovery: estimates of milkweeds lost, milkweeds remaining and milkweeds that must be added to increase the monarch population. Insect Conservation and Diversity 10, 42-53. https://doi.org/10.1111/icad.12198

Pocock, M.J.O., Schmucki, R., Bohan, D.A., 2020. Inferring species interactions from ecological survey data: a mechanistic approach to predict quantitative food webs of seed-feeding by carabid beetles. bioRxiv 2020.11.09.375402. https://doi.org/10.1101/2020.11.09.375402

Richner, N., Holderegger, R., Linder, H.P., Walter, T., 2015. Reviewing change in the arable fl ora of Europe: a meta-analysis. Weed Research 55, 1-13. https://doi.org/10.1111/wre.12123

Rosseel, Y., 2012. Iavaan : An R Package for Structural Equation Modeling. Journal of Statistical Software 48. https://doi.org/10.18637/jss.v048.i02

Scott, R.J., Baker, P., Bell, D., Bennett, S., Birchall, C., Boffey, C.W.H., Bohan, D.A., Brooks, D.R., Browne, E.L., Champion, G.T., Clark, S.J., Daniels, R.E., Dewar, A.J.G., Dewar, A.M., Fairfax, C.M., Firbank, L.G., Garner, B.H., Haughton, A.J., Hawes, C., Haylock, L.A., Heard, M.S., Hill, M.O., Horne, S.L., Hulmes, S.E., Mason, N.S., May, M.J., Norton, L. R., Nuttall, P., Osborne, J.L., Parish, A.M., Perry, J.N., Randle, Z., Rossall, M.J., Rothery, P., Roy, D. B., Sands, R.J.N., Singer, E.J., Skellern, M.P., Squire, G.R., Thomas, M.R., Walker, J.H., Walker, M.J., Woiwod, I.P., Wood, C.M., Young, M.W., 2012a. Farm scale evaluations of herbicide tolerant genetically modified crops - beet.

https://doi.org/10.5285/86cd1a60-64f1-4087-a9f1-a3d8a9f8f535 
Scott, R.J., Baker, P., Bell, D., Bennett, S., Birchall, C., Boffey, C.W.H., Bohan, D.A., Brooks, D.R., Browne, E.L., Champion, G.T., Clark, S.J., Daniels, R.E., Dewar, A.J.G., Dewar, A.M., Fairfax, C.M., Firbank, L.G., Garner, B.H., Haughton, A.J., Hawes, C., Haylock, L.A., Heard, M.S., Hill, M.O., Horne, S.L., Hulmes, S.E., Mason, N.S., May, M.J., Norton, L. R., Nuttall, P., Osborne, J.L., Parish, A.M., Perry, J.N., Randle, Z., Rossall, M.J., Rothery, P., Roy, D.B., Sands, R.J.N., Singer, E.J., Skellern, M.P., Squire, G.R., Thomas, M.R., Walker, J.H., Walker, M.J., Woiwod, I.P., Wood, C.M., Young, M.W., 2012b. Farm scale evaluations of herbicide tolerant genetically modified crops - maize.

https://doi.org/10.5285/ca6752ed-3a22-4790-a86d-afadaedda082

Scott, R.J., Baker, P., Bell, D., Bennett, S., Birchall, C., Boffey, C.W.H., Bohan, D.A., Brooks, D.R., Browne, E.L., Champion, G.T., Clark, S.J., Daniels, R.E., Dewar, A.J.G., Dewar, A.M., Fairfax, C.M., Firbank, L.G., Garner, B.H., Haughton, A.J., Hawes, C., Haylock, L.A., Heard, M.S., Hill, M.O., Horne, S.L., Hulmes, S.E., Mason, N.S., May, M.J., Norton, L. R., Nuttall, P., Osborne, J.L., Parish, A.M., Perry, J.N., Randle, Z., Rossall, M.J., Rothery, P., Roy, D.B., Sands, R.J.N., Singer, E.J., Skellern, M.P., Squire, G.R., Thomas, M.R., Walker, J.H., Walker, M.J., Woiwod, I.P., Wood, C.M., Young, M.W., 2012c. Farm scale evaluations of herbicide tolerant genetically modified crops - spring oilseed rape. https://doi.org/10.5285/0023bd6e-4dd7-462c-aacf-f13083b054ab

Scott, R.J., Baker, P., Bell, D., Bennett, S., Birchall, C., Boffey, C.W.H., Bohan, D.A., Brooks, D.R., Browne, E.L., Champion, G.T., Clark, S.J., Daniels, R.E., Dewar, A.J.G., Dewar, A.M., Fairfax, C.M., Firbank, L.G., Garner, B.H., Haughton, A.J., Hawes, C., Haylock, L.A., Heard, M.S., Hill, M.O., Horne, S.L., Hulmes, S.E., Mason, N.S., May, M.J., Norton, L. R., Nuttall, P., Osborne, J.L., Parish, A.M., Perry, J.N., Randle, Z., Rossall, M.J., Rothery, P., Roy, D.B., Sands, R.J.N., Singer, E.J., Skellern, M.P., Squire, G.R., Thomas, M.R., Walker, J.H., Walker, M.J., Woiwod, I.P., Wood, C.M., Young, M.W., 2012d. Farm scale evaluations of herbicide tolerant genetically modified crops - winter oilseed rape.

https://doi.org/10.5285/37a503da-d75c-4d72-8e8b-b11c2fdc7d92

Silva, V., Mol, H.G.J., Zomer, P., Tienstra, M., Ritsema, C.J., Geissen, V., 2019. Pesticide residues in European agricultural soils -A hidden reality unfolded. Science of The Total Environment 653, 15321545. https://doi.org/10.1016/j.scitotenv.2018.10.441

Smart, S.M., Firbank, L.G., Bunce, R.G.H., Watkins, J.W., 2000. Quantifying changes in abundance of food plants for butterfly larvae and farmland birds. Journal of Applied Ecology 37, 398-414. https://doi.org/10.1046/j.1365-2664.2000.00508.x

Smid, S.C., McNeish, D., Miočević, M., Schoot, R. van de, 2020. Bayesian Versus Frequentist Estimation for Structural Equation Models in Small Sample Contexts: A Systematic Review. Structural Equation Modeling: A Multidisciplinary Journal 27, 131-161.

https://doi.org/10.1080/10705511.2019.1577140

Sutcliffe, O.L., Kay, Q.O.N., 2000. Changes in the arable flora of central southern England since the 1960s. Biological Conservation 93, 1-8. https://doi.org/10.1016/S0006-3207(99)00119-6

Trichard, A., Ricci, B., Ducourtieux, C., Petit, S., 2014. The spatio-temporal distribution of weed seed predation differs between conservation agriculture and conventional till age. Agriculture, Ecosystems \& Environment 188, 40-47. https://doi.org/10.1016/j.agee.2014.01.031

Watkinson, A.R., Freckleton, R.P., Robinson, R.A., Sutherland, W.J., 2000. Predictions of biodiversity response to genetically modified herbicide-tolerant crops. Science 289, 1554-1557. 
bioRxiv preprint doi: https://doi.org/10.1101/2020.12.04.411918; this version posted December 4, 2020. The copyright holder for this preprint (which was not certified by peer review) is the author/funder, who has granted bioRxiv a license to display the preprint in perpetuity. It is made available under aCC-BY 4.0 International license.

\section{Supplementary material}

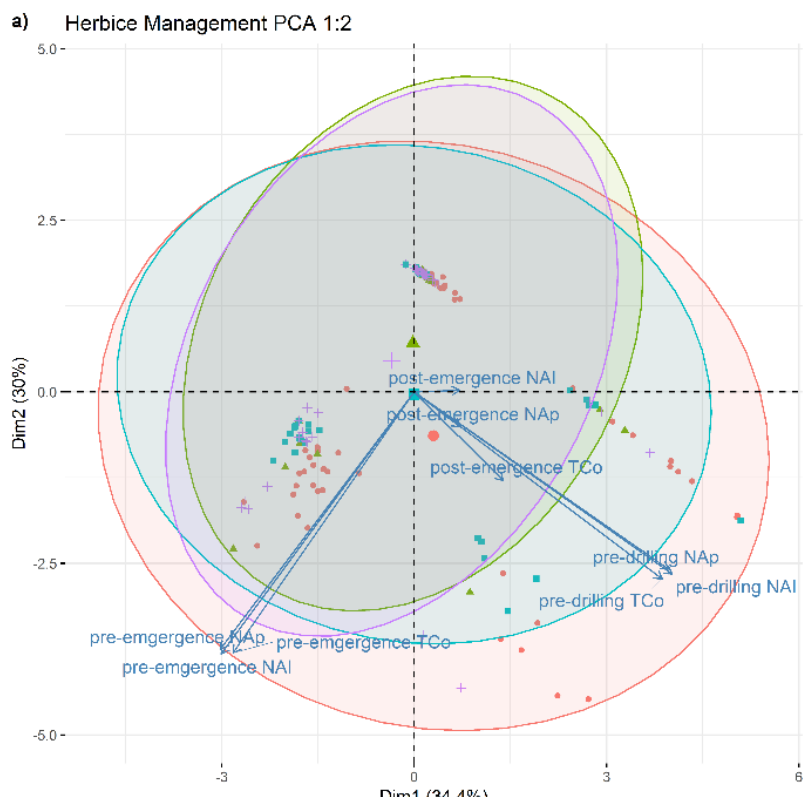

c) Active Ingredient PCA 1:2

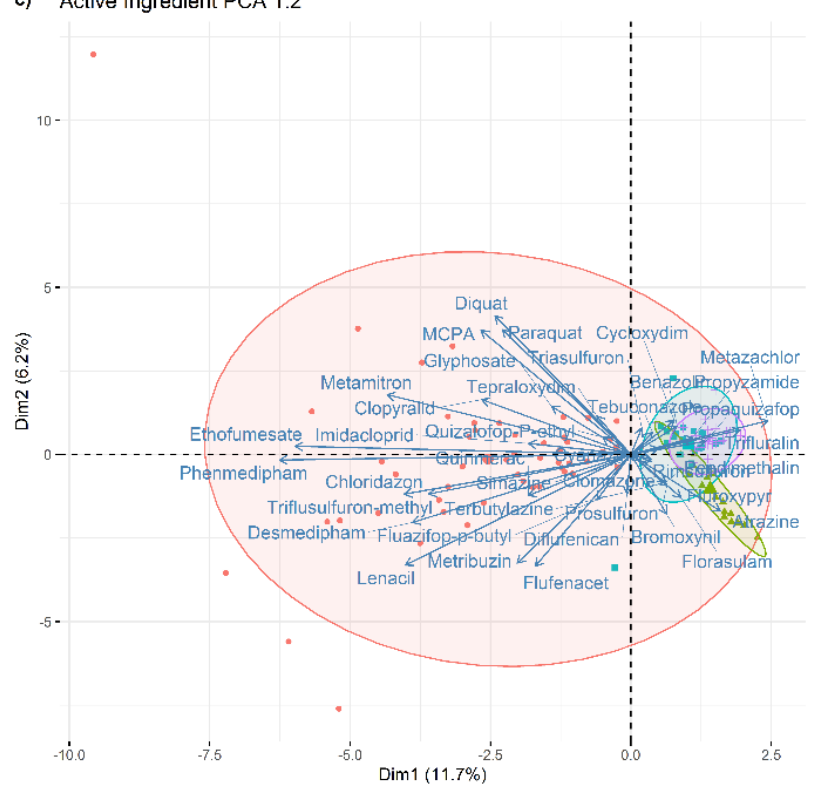

b) Herbice Management PCA 1:3

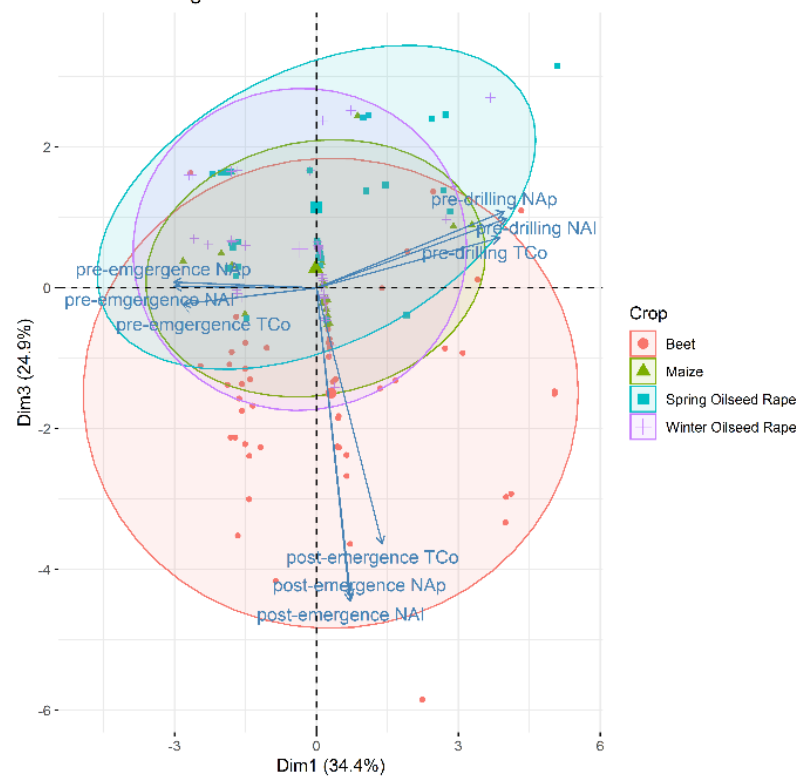

d) Active Ingredient PCA 1:3

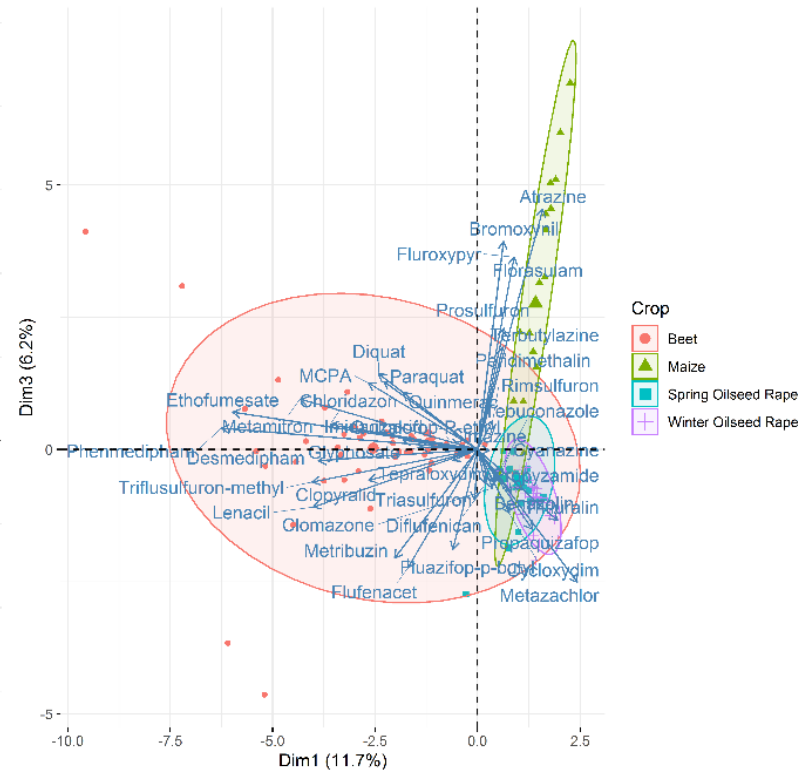

Figure S1 Principal Component Analysis (PCA) results with a) the first and second components and b) the first and third components of the total amount of herbicide applied per hectare (TCO), the number of application (Nap) and the number of active ingredients (NAI) applied on four conventional crops (spring-sown beet, spring-sown maize, spring-sown oilseed rape and wintersown oilseed rape) grown across 168 fields monitored during the Farm Scale Evaluation field trials. c) The first and second components and d) the first and third components of the PCA computed on active ingredients (frequency and diversity) used in four crops across 168 fields. 

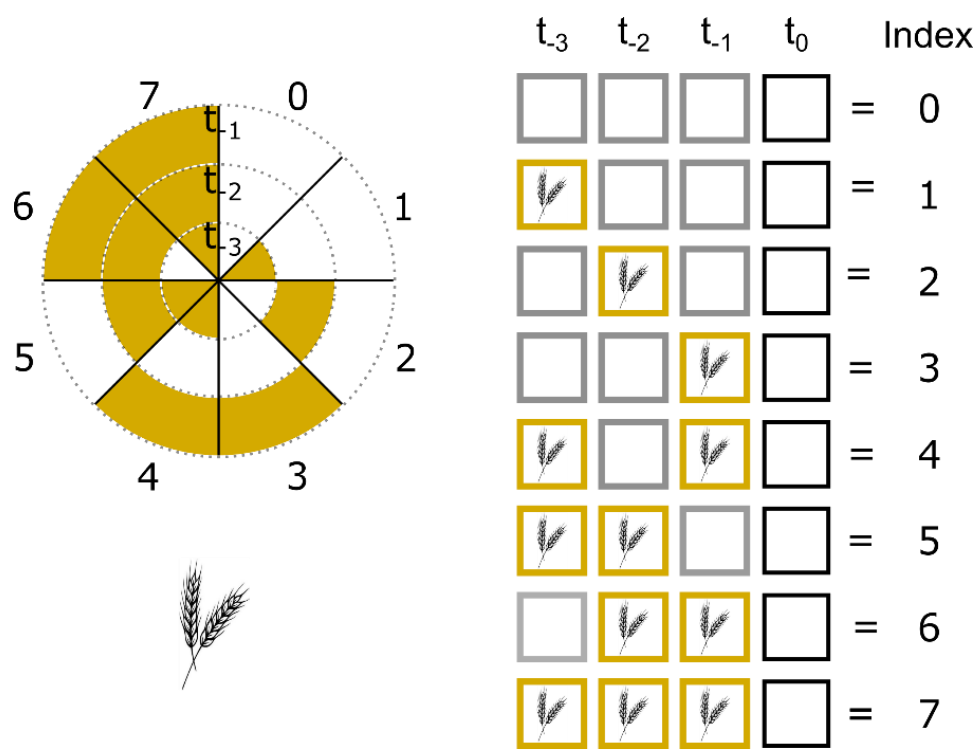

Figure $\mathbf{S 2}$ Schematic representation of the index used to integrate the cereal (illustrate above) and the winter-sown component contained in the crop sequence (rotation) observed in the three years preceding the sampling of the reference seedbank $\left(t_{0}\right)$ in the Farm Scale Evaluation field trials. Ranging from 0 to 7, the index represents the change in consecutiveness and recentness of the focal state (cereal crop or winter-sown crop), where 0 indicates the absence of the focal state and 7 indicates a continuous sequence over the 3-year period. 